\title{
Further studies on various aspects of the use of high-copper supplements for growing pigs
}

\author{
By M. M. ALLEN, R. S. BARBER, R. BRAUDE AND K. G. MITCHELL \\ National Institute for Research in Dairying, Shinfield, Reading \\ (Received 7 February 1961-Revised 24 April 1961)
}

The growth-promoting effect of the addition of $0 \cdot$ I $\%$ copper sulphate (supplying $25^{\circ}$ p.p.m. $\mathrm{Cu}$ ) to a growing-pig diet, reported by Barber, Braude, Mitchell \& Cassidy (I955), has since been confirmed in many experiments both in Europe and America.

In the present paper results of four further experiments are given dealing with: ( $\mathrm{r}$ ) the optimal level of copper sulphate to include in the diet; (2) comparison of copper sulphate and copper carbonate, in diets given at two different levels; (3) comparison of the effect of copper sulphate in diets containing dried skim milk as the protein supplement in place of white-fish meal; and (4) effect of system of feeding ('semiad lib.', wet, or 'fully ad lib.', dry) on the response to copper sulphate.

\section{EXPERIMENTAL}

Pigs and their management. In all four experiments, weaners from the Shinfield, virus pneumonia-free, Large White herd were used and were all individually fed. Each experiment was designed in randomized blocks, blocks corresponding to litters, and treatments were allocated at random to the pens. In Expts $\mathrm{I}-3$ the pigs were kept in pens of four or six pigs each, whereas in Expt 4 the pigs were kept individually in separate pens. Expt 2 was designed as a $3 \times 2$ factorial and Expt 4 as a $2 \times 2$ factorial. There was no direct communication between pigs on different treatments in any experiment. The numbers of pigs on each treatment were fourteen in Expt I, eight each in Expts 2 and 3 and six in Expt 4.

In Expts $\mathrm{I}$ and 3 all pigs were given twice daily as much meal as they would consume within $30 \mathrm{~min}$ up to a maximum of $6 \frac{1}{2} \mathrm{lb} /$ day, water at the rate of $3 \mathrm{lb}$ to every I $\mathrm{lb}$ meal being added immediately before feeding. This system of feeding has been used extensively at Shinfield and has been termed 'semi-ad lib.'; it was also used for the pigs on treatments 4, 5 and 6 in Expt 2 and treatments $I$ and 2 in Expt 4. Pigs on treatments I, 2 and 3 in Expt 2 were also given meal twice daily, $3 \mathrm{lb}$ water per $\mathrm{I} \mathrm{lb}$ of meal again being added immediately before feeding, but the amount of meal given was based on live weight and according to a scale (Braude \& Mitchell, I95 I), a daily maximum of $6 \frac{1}{2} \mathrm{lb} / \mathrm{pig}$ being given to an animal weighing $170 \mathrm{lb}$. For pigs on treatments 3 and 4 in Expt 4 dry meal was available in unrestricted amounts up to a daily maximum of approximately $6 \frac{3}{4} \mathrm{lb} / \mathrm{pig}$; water from an automatic bowl was available in each pen. 
All pigs were weighed once weekly throughout the experiments, the rations of the pigs on treatments I, 2 and 3 in Expt 2, which were fed to scale, being adjusted after each weekly weighing. In each experiment, except Expt 4, all the pigs were sent to slaughter individually when their live weight at the weekly weighing exceeded $203 \mathrm{lb}$. In Expt 4, only those pigs on treatments 3 and 4 were continued on experiment to bacon weight, the remainder finishing after 9 weeks on experiment. At the factory all carcasses, except those from pigs in Expt 4, were commercially graded according to the system in force at the time of slaughter. Pigs in Expts $I$ and 2 were graded according to back-fat thickness only, whereas for those in Expt 3 carcass length was also taken into account.

Diets and treatments. Table I gives the composition of the basal diets used, and in Table 2 details of the treatments in the four experiments are shown.

Estimation of copper content of the liver. In Expts I and 2 a sample of liver tissue adjacent to the bile duct was taken at slaughter from each pig and stored at $-20^{\circ}$ (see Barber, Braude \& Mitchell, I960). The Cu content of the samples was subsequently determined by the method of Andrus (1955).

Table I. Percentage composition of the basal diets

\begin{tabular}{lccc} 
& \multicolumn{3}{c}{ Diet no. } \\
\cline { 2 - 3 } & $\mathrm{I}^{*}$ & $2 \dagger$ & $3 f$ \\
Barley meal & 52 & 65 & $4 \mathrm{I}$ \\
Fine miller's offal & 38 & 30 & 38 \\
White-fish meal & I0 & 5 & - \\
Dried skim milk & - & - & 20 \\
Steamed bone flour & - & - & $\mathbf{I}$ \\
Rovimix (Roche Products Ltd) & $4 \cdot 5$ & $2 \cdot 0$ & $4 \cdot 5$
\end{tabular}

* Used throughout experimental period for control pigs in Expts I and 4, on treatment I in Expt 3 , and in Expt 2 up to 120 lb individual live weight.

$\uparrow$ Used for control pigs in Expt 2 from $120 \mathrm{lb}$ individual live weight to slaughter.

I Used throughout experimental period for pigs on treatment 3 in Expt 3 .

$\S$ Containing 50000 i.u. vitamin $A$ and 12500 i.u. vitamin $D_{3} / g$.

\section{RESULTS}

The mean results for daily weight gain, food conversion efficiency and rate of food consumption, together with appropriate standard errors for Expts I, 2, 3 and 4, are given in Tables 3, 4, 6 and 7 respectively.

The results of the appropriate analyses for Expt $2(3 \times 2$ factorial $)$ and for Expt 4 $(2 \times 2$ factorial $)$ are given in Tables 5 and 8 respectively, with the standard errors and statistical significance of the treatment effects and interactions.

In Table 9 the results for those pigs in Expt 4 (treatments 3 and 4) that continued on experiment to bacon weight are shown.

Information about dressing percentage is included in Tables 3,4 and 6 and about carcass length in Table 6 . In Tables 3 and 4 figures for the $\mathrm{Cu}$ content of the liver of pigs in Expts $\mathrm{I}$ and 2 are also given. The standard errors were calculated from 
Vol. I 5

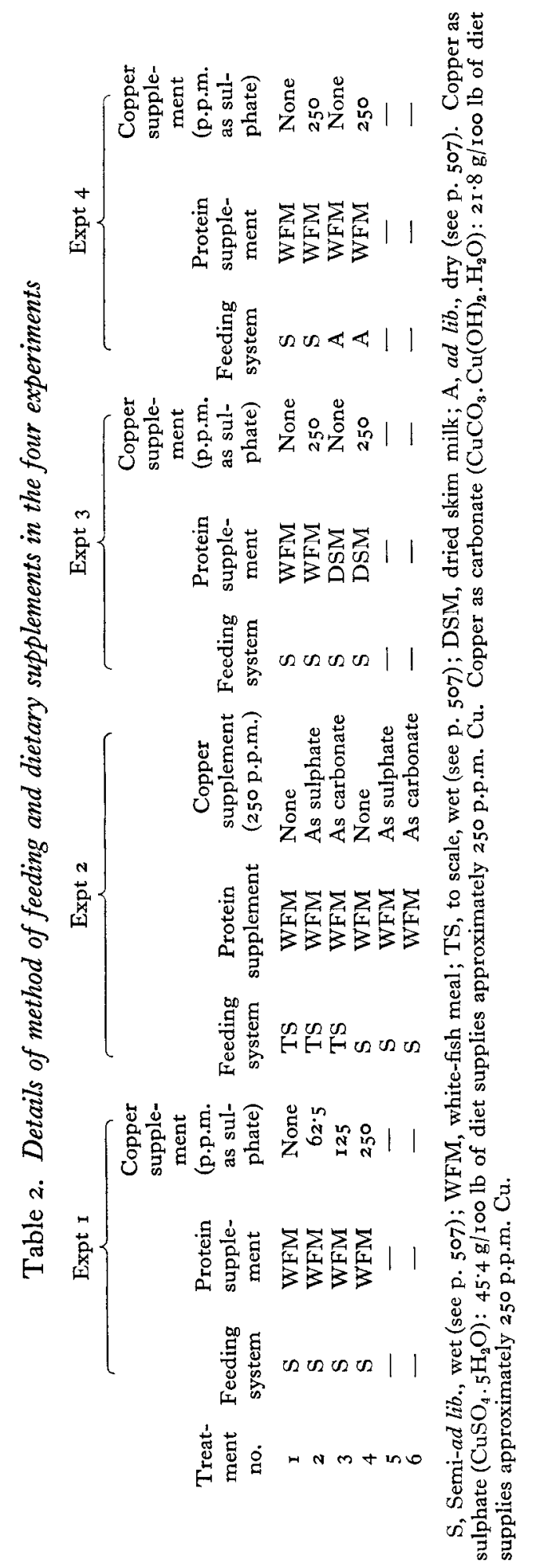


randomized block analyses of variance, no adjustments being made for variation in either initial live weight or cold dead weight (see Barber, Braude \& Mitchell, 1957). Under our conditions of experimentation the term 'treatment' is confounded with 'pen' but the 'pen' effect has been considered as negligible. The commercial grading results for the pigs in Expts I, 2 and 3 are presented in Tables IO, I I and I 2 respectively. In Table $\mathrm{I}_{3}$, the responses in rate of gain and efficiency of food utilization to $\mathrm{Cu}$ supplementation in the four experiments are expressed as percentages of the results for the corresponding unsupplemented control animals.

The general health of the pigs on the experiments was satisfactory. Of the total of I 60 pigs involved in the four experiments, five had to be removed from experiment or died for reasons unconnected with the trials.

Table 3. Expt I. Effect of supplementation of diets with different amounts of copper sulphate on mean daily weight gain, food conversion, rate of food consumption, dressing percentage, and liver copper stores

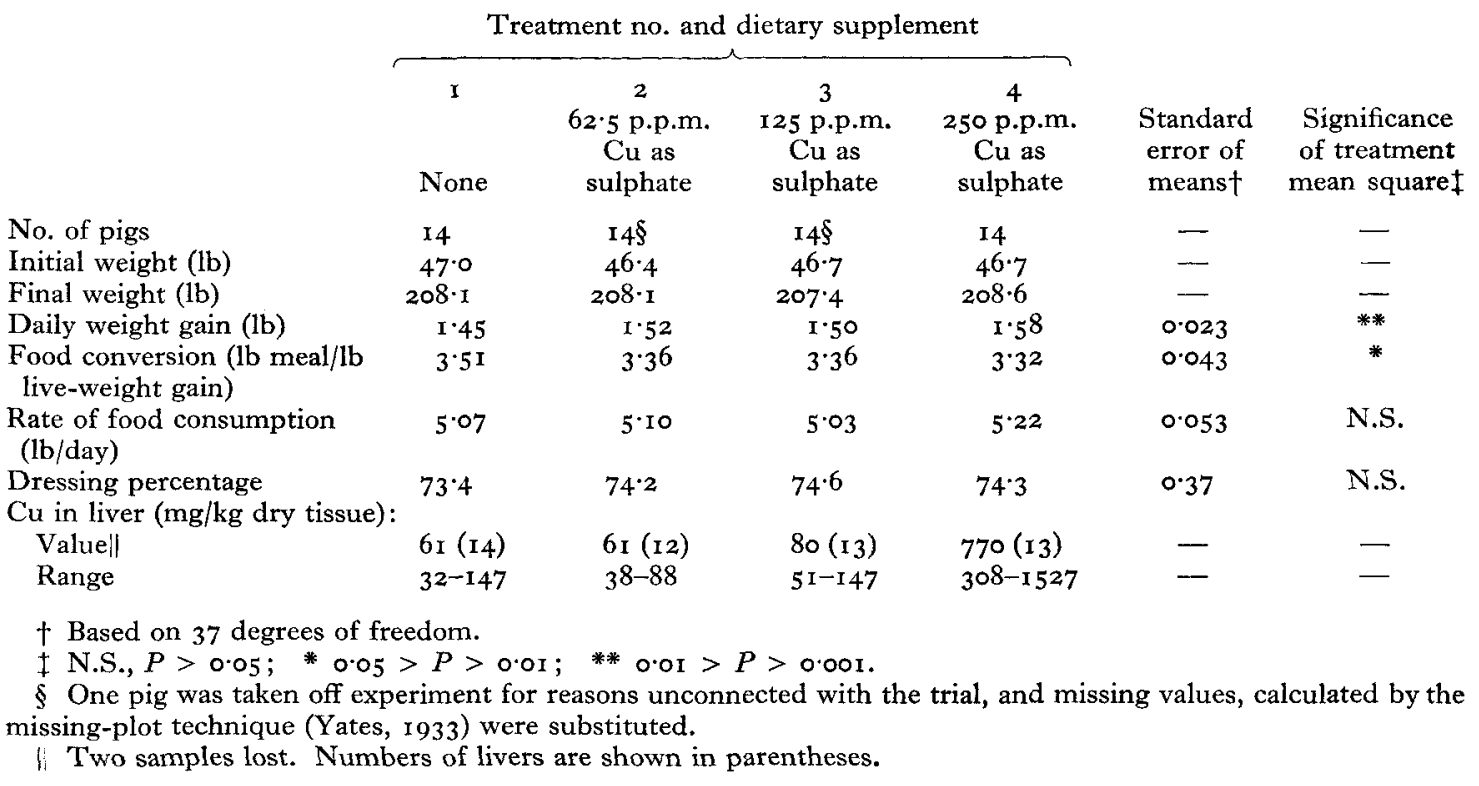

\section{Expt I (Tables 3 and Io)}

Rate of gain and efficiency of food utilization. Supplementation of the basal diet with copper sulphate at each of the three levels resulted in significant improvements in both rate of gain and efficiency of food utilization. The rate of gain of the pigs given the highest level of $\mathrm{Cu}$ (treatment 4,25 p.p.m. Cu) was significantly greater than that of the pigs on treatment 3 (125 p.p.m. Cu) $(P<0.05)$, but there were no significant differences in the efficiency with which the three groups given $\mathrm{Cu}$ utilized their food.

Rate of food consumption. The mean figures indicated that the rate of food consumption of the pigs given $25^{\circ}$ p.p.m. Cu in their diet was higher than that of the other three groups. Although the treatment mean square for this variable was not quite significant 
Vol. I5

Copper supplements for growing pigs

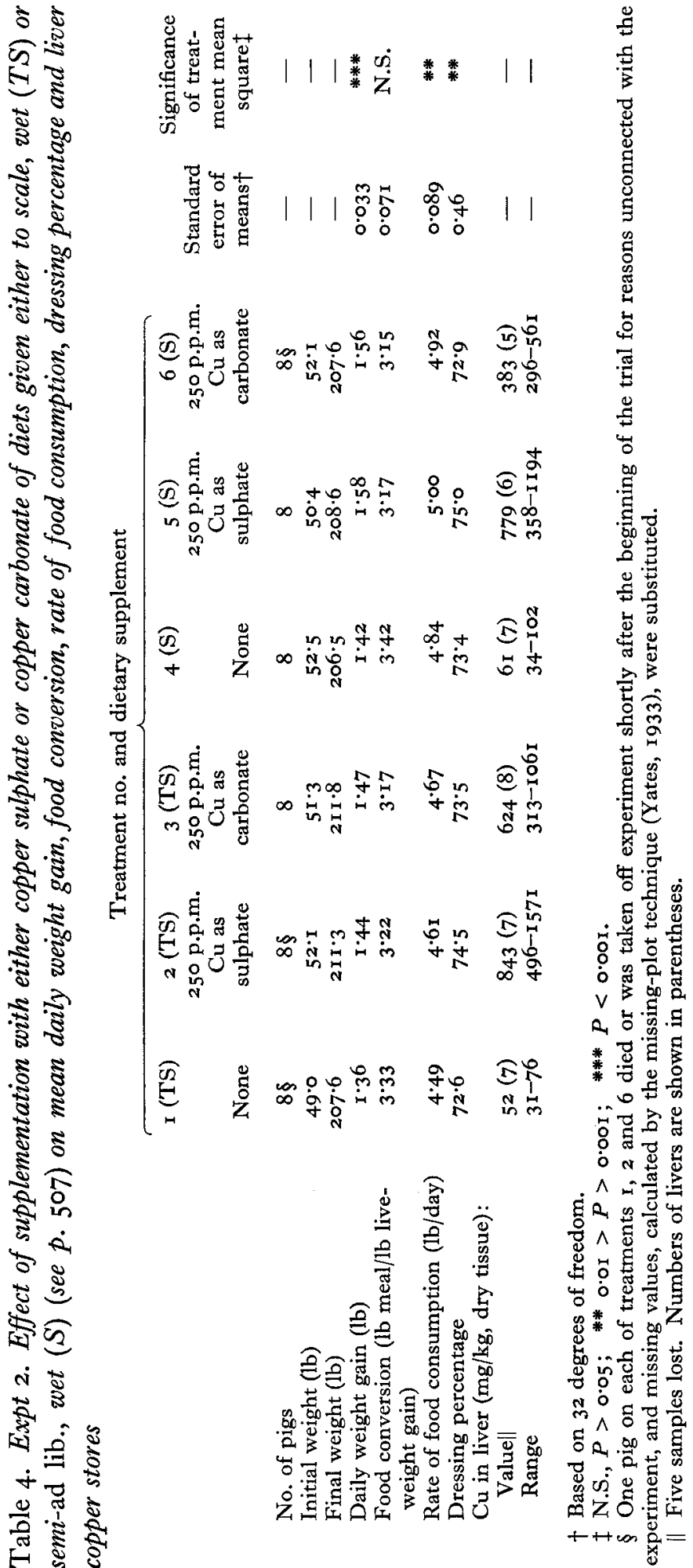




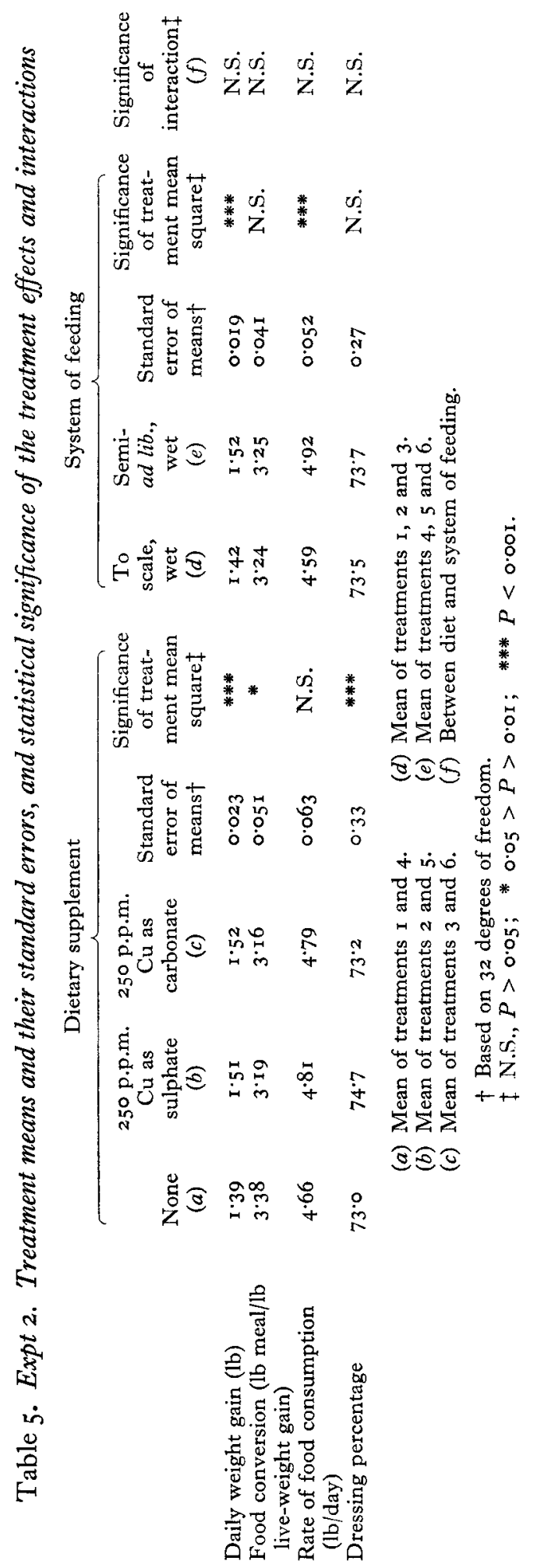


at the $5 \%$ level, a $t$ test indicated that the differences between treatment 4 (250 p.p.m. $\mathrm{Cu}$ ) and treatments I (control) and 3 (I25 p.p.m. Cu) were statistically significant $(P<0.05)$.

Dressing percentage. Differences in dressing percentage were not significant, although the mean figures indicated a trend for a small increase in dressing percentage when the basal diet was supplemented with copper sulphate at either of the three levels.

Liver copper stores. There was little or no increase in liver $\mathrm{Cu}$ stores at slaughter when diets supplemented with either 62.5 or 125 p.p.m. Cu were given, but with a supplement of $25^{\circ}$ p.p.m. Cu (treatment 4 ) there was a marked increase.

Table 6. Expt 3. Effect of supplementation with copper sulphate of diets containing either white-fish meal (WFM) or dried skim milk (DSM) as the protein supplement on mean daily weight gain, food conversion, rate of food consumption, dressing percentage and carcass length

Treatment no. and dietary supplement

No. of pigs

Initial weight (lb)

Final weight (lb)

Daily weight gain (lb)

Food conversion (lb meal/lb

live-weight gain)

Rate of food consumption

(lb/day)

Dressing percentage

Carcass length $(\mathrm{mm})$

\begin{tabular}{|c|c|c|c|c|c|}
\hline I (WFM) & $2($ WFM $)$ & 3 (DSM) & $4(\mathrm{DSM})$ & & \\
\hline None & $\begin{array}{l}\text { 250 p.p.m. } \\
\text { Cu as } \\
\text { sulphate }\end{array}$ & None & $\begin{array}{c}\text { 250 p.p.m. } \\
\text { Cu as } \\
\text { sulphate }\end{array}$ & $\begin{array}{l}\text { Standard } \\
\text { error of } \\
\text { means } \uparrow\end{array}$ & $\begin{array}{c}\text { Significance } \\
\text { of treatment } \\
\text { mean square }\end{array}$ \\
\hline 8 & 8 & 8 & 8 & - & - \\
\hline $47 \cdot 2$ & $4^{8 \cdot 4}$ & $47^{\circ} 9$ & $47 \cdot 8$ & - & - \\
\hline 210.1 & $208 \cdot 6$ & $210 \cdot 6$ & $209 \cdot 9$ & - & - \\
\hline $\mathrm{I} \cdot 53$ & $I \cdot 57$ & I'57 & I.76 & 0.032 & $* * *$ \\
\hline $3 \cdot 24$ & $3 \cdot 22$ & $3 \cdot 10$ & 3.02 & 0.067 & N.S. \\
\hline $4 \cdot 94$ & 5.03 & $4 \cdot 85$ & $5 \cdot 29$ & 0.072 & $* *$ \\
\hline $73 \cdot 4$ & $74 \cdot x$ & $73 \cdot 4$ & $73 \cdot 8$ & 0.49 & N.S. \\
\hline 791 & 784 & 784 & 784 & $6 \cdot 0$ & N.S. \\
\hline
\end{tabular}

$\uparrow$ Based on 21 degrees of freedom.

† N.S., $P>0.05$; ** 0.01 $>P>0.001$; *** $P<0.001$.

Table 7. Expt 4 (a). Effect of supplementation with copper sulphate of diets given either semi-ad lib., wet $(S)$ or ad lib., $d r y(A)($ see $p .507)$ to pigs on experiment for 9 weeks after weaning on mean daily weight gain, food conversion and rate of food consumption

Treatment no. and dietary supplement

\begin{tabular}{|c|c|c|c|c|c|}
\hline I (S) & $\begin{array}{c}2(\mathrm{~S}) \\
25 \circ \text { p.p.m. } \\
\text { Cu as } \\
\text { sulphate }\end{array}$ & $3(\mathrm{~A})$ & $\begin{array}{c}4(\mathrm{~A}) \\
25 \circ \mathrm{p} \cdot \mathrm{p} \cdot \mathrm{m} . \\
\text { Cu as } \\
\text { sulphate }\end{array}$ & $\begin{array}{l}\text { Standard } \\
\text { error of } \\
\text { meanst }\end{array}$ & $\begin{array}{c}\text { Significance } \\
\text { of treatment } \\
\text { mean square } \downarrow\end{array}$ \\
\hline 6 & 6 & 6 & 6 & - & - \\
\hline $43 \cdot 8$ & $45^{\circ} \circ$ & $45 \cdot 5$ & $45 \cdot 8$ & - & - \\
\hline 133.8 & $147 \cdot 3$ & $130 \cdot 2$ & 140.0 & - & - \\
\hline I. 43 & $I \cdot 62$ & I. 35 & $I \cdot 49$ & 0.045 & ** \\
\hline 3.04 & $2 \cdot 94$ & $3 \cdot 35$ & $3 \cdot 17$ & 0.073 & $* *$ \\
\hline $4^{\prime} 3^{I}$ & $4 \cdot 78$ & $4: 49$ & 4.72 & 0.13 & N.S. \\
\hline
\end{tabular}

No. of pigs

Initial weight (lb)

Final weight (lb)

Daily weight gain (lb)

Food conversion (lb meal/lb

live-weight gain)

Rate of food consumption (lb/day) 


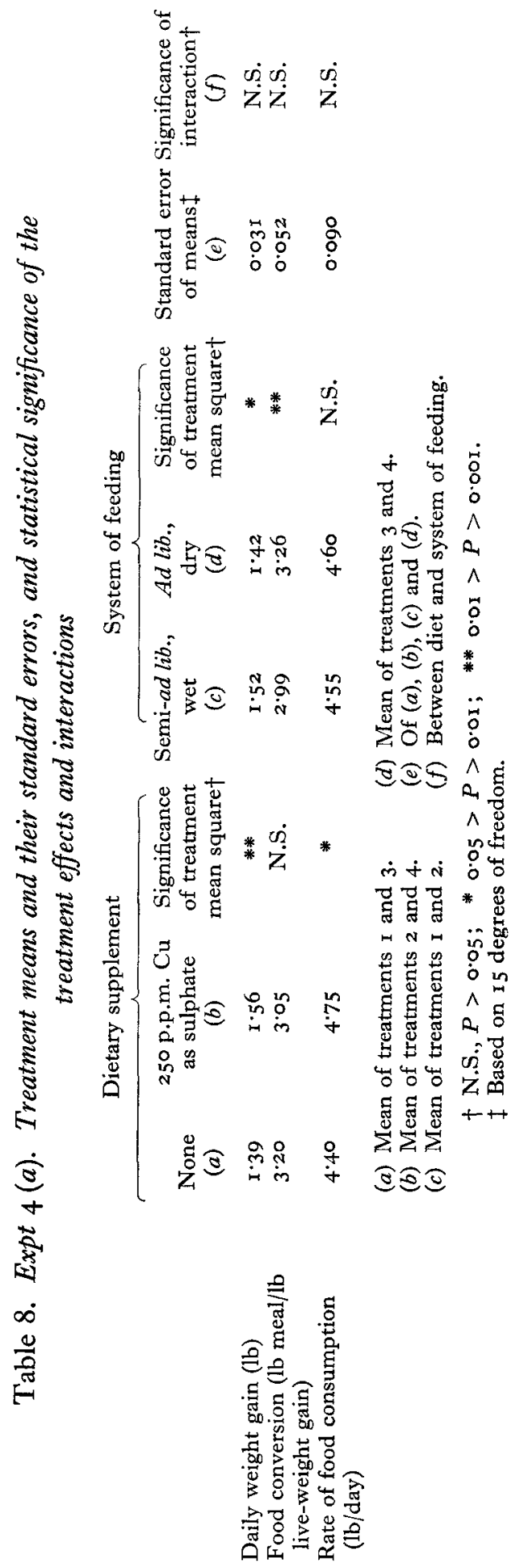


Commercial grading (Table ro). There were no marked differences in the commercial grading, based on back-fat thickness, of the carcasses from the four groups of pigs.

\section{Expt 2 (Tables 4, 5 and II)}

Rate of gain. Supplementation of the basal diet with $25^{\circ}$ p.p.m. Cu either as the sulphate or as the carbonate increased the rate of gain of the pigs whether fed to scale or semi-ad lib. These differences were all statistically significant except that pigs fed to scale and given a diet supplemented with $\mathrm{Cu}$ as the sulphate (treatment 2) did not grow significantly faster than the corresponding controls (treatment $\mathrm{r}$ ). The values in Table 5 show that both $\mathrm{Cu}$ salts were equally effective in increasing the rate of gain, and that the rate of gain of the pigs fed semi-ad lib. was significantly greater than that of the pigs fed to scale $(P<0.001)$.

The percentage improvement in rate of gain due to the copper supplement was greater when feeding was semi-ad lib. than when it was to scale (see Table 13 ).

Efficiency of food utilization. Supplementation of the diet with either copper

Table 9. Expt 4 (b). Mean results for treatments 3 and 4 (see Table 7 ) from weaning to bacon weight

(The amount of meal fed dry to both groups was limited to a daily maximum of $6 \frac{3}{4} \mathrm{lb} / \mathrm{pig}$ )

\begin{tabular}{|c|c|c|c|c|}
\hline & \multicolumn{2}{|c|}{$\begin{array}{l}\text { Treatment no. and } \\
\text { dietary supplement }\end{array}$} & \multirow[b]{2}{*}{$\begin{array}{l}\text { Standard } \\
\text { error of } \\
\text { means† }\end{array}$} & \multirow{2}{*}{$\begin{array}{c}\text { Statistical } \\
\text { significance } \\
\text { of difference } \\
\text { in means } \ddagger\end{array}$} \\
\hline & $\begin{array}{c}3 \\
\text { None }\end{array}$ & $\begin{array}{c}4 \\
25^{\circ} \text { p.p.m. Cu } \\
\text { as sulphate }\end{array}$ & & \\
\hline No. of pigs & 6 & 6 & - & - \\
\hline Initial weight (lb) & $45 \cdot 5$ & $45 \cdot 8$ & 一 & - \\
\hline Final weight (lb) & $206 \cdot 6$ & $209^{\circ} 0$ & - & - \\
\hline Daily weight gain (lb) & $I \cdot 4 I$ & I.54 & 0.034 & * \\
\hline $\begin{array}{l}\text { Food conversion (lb meal/lb live- } \\
\text { weight gain) }\end{array}$ & $3 \cdot 84$ & $3 \cdot 59$ & 0.074 & N.S. \\
\hline Rate of food consumption (lb/day) & $5 \cdot 43$ & $5 \cdot 49$ & 0.093 & N.S. \\
\hline \multicolumn{5}{|l|}{$\mathrm{Cu}$ in liver (mg/kg dry tissue): } \\
\hline Value§ & $28(6)$ & $343(4)$ & - & $一$ \\
\hline Range & $17-42$ & $109-500$ & - & - \\
\hline
\end{tabular}

Table 10. Commercial grading of pigs on Expt $\mathrm{I}$

\begin{tabular}{|c|c|c|c|c|c|c|c|c|c|c|c|c|}
\hline \multirow{3}{*}{$\begin{array}{l}\text { Copper } \\
\text { supplement } \\
\text { (p.p.m.) }\end{array}$} & \multicolumn{12}{|c|}{ No. of pigs } \\
\hline & \multirow[b]{2}{*}{ Total } & \multicolumn{3}{|c|}{$\begin{array}{l}\text { With loin fat } \\
\text { grading }\end{array}$} & & \multicolumn{4}{|c|}{$\begin{array}{l}\text { With shoulder fat } \\
\text { grading }\end{array}$} & \multicolumn{3}{|c|}{$\begin{array}{c}\text { With mid-back fat } \\
\text { grading }\end{array}$} \\
\hline & & A & B & $\mathrm{C}$ & $\mathbf{F}$ & A & B & $\mathrm{C}$ & $\mathbf{F}$ & A & B & $\mathrm{C}$ \\
\hline None & 14 & 7 & 3 & 3 & I & 7 & 3 & 3 & I & IO & 3 & 0 \\
\hline $62 \cdot 5$ & 13 & 7 & 4 & I & $\mathbf{I}$ & 7 & 6 & o & o & 12 & $\mathbf{I}$ & $\circ$ \\
\hline 125 & I3 & 7 & 4 & 0 & 2 & 8 & 2 & 3 & o & Io & $\mathbf{I}$ & I \\
\hline 250 & 14 & 9 & 2 & 2 & $\mathbf{I}$ & 6 & 3 & 4 & I & IO & 4 & 0 \\
\hline
\end{tabular}


sulphate or copper carbonate similarly and significantly $(P<0.05)$ improved the efficiency of food utilization (Table 5). The values in Table 4 show, however, that the difference in food utilization was not statistically significant for the pigs fed to scale but was so, as judged by a $t$ test, when the pigs were fed semi-ad lib. $(P<0 \cdot 05)$. The system of feeding (to scale or semi-ad lib.) had no significant effect on the efficiency of food utilization (Table 5).

Table I I. Commercial grading of pigs on Expt 2

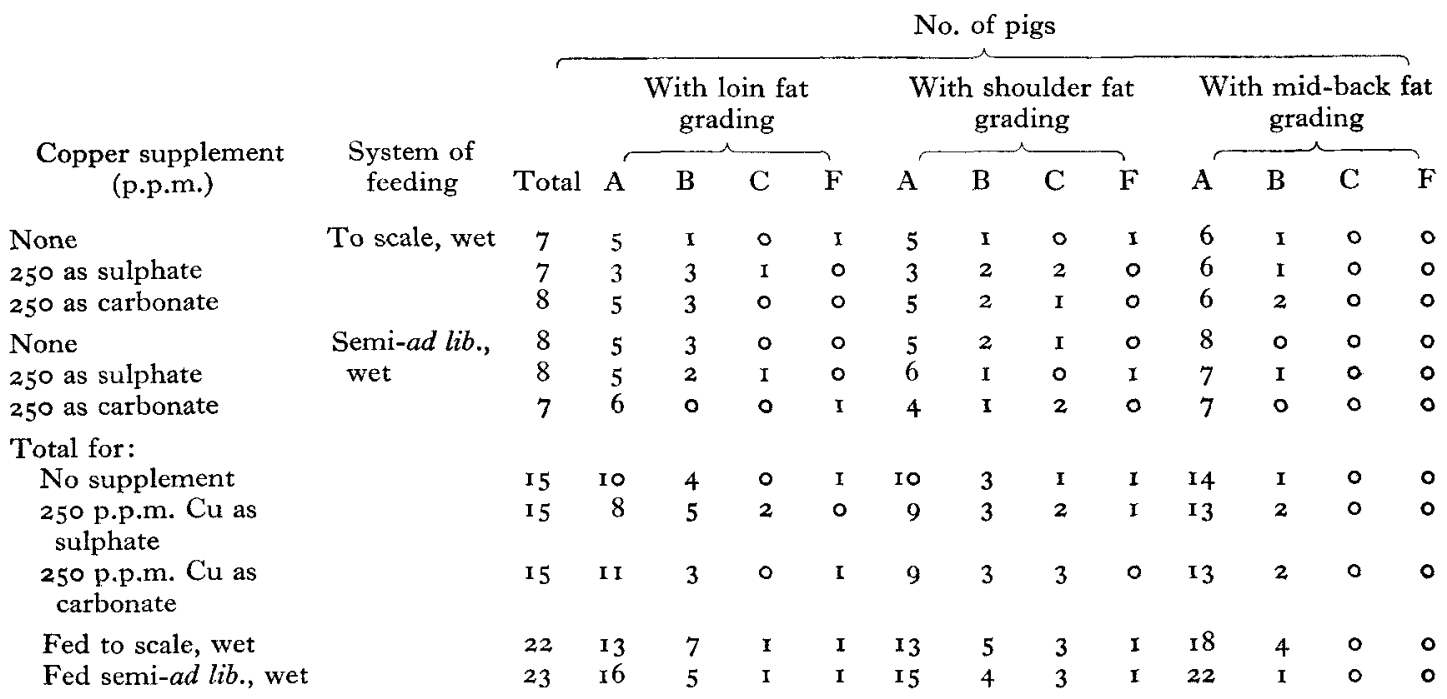

Table 12. Commercial grading of pigs on Expt 3

\begin{tabular}{|c|c|c|c|c|c|c|c|c|c|c|c|c|}
\hline \multirow[b]{2}{*}{$\begin{array}{c}\text { Protein } \\
\text { supplement }\end{array}$} & \multirow[b]{2}{*}{$\begin{array}{c}\text { Copper } \\
\text { supple- } \\
\text { ment } \\
\text { (p.p.m.) }\end{array}$} & \multicolumn{11}{|c|}{ No. of pigs } \\
\hline & & Total & $\mathrm{AA}+$ & $\mathrm{AA}$ & A & $\begin{array}{c}\text { Total A } \\
\text { and } \\
\text { above }\end{array}$ & $\mathbf{B}+$ & B & $\mathrm{C}$ & $\mathrm{F}$ & $\overbrace{\text { Loin }}^{\text {Gra }}$ & $\overbrace{\text { Shoulder }}^{A \text { on }}$ \\
\hline White-fish meal & None & 8 & 2 & 2 & I & 5 & 2 & o & $\mathbf{I}$ & $\circ$ & 5 & 7 \\
\hline & 250 & 8 & $\mathbf{I}$ & 2 & $\mathbf{I}$ & 4 & 4 & $\circ$ & $\circ$ & $\circ$ & 4 & 5 \\
\hline Dried skim milk & None & 8 & $\mathbf{I}$ & 2 & 2 & 5 & 2 & I & $\circ$ & $\circ$ & 5 & 8 \\
\hline & 250 & 8 & 2 & 2 & $\circ$ & 4 & $\circ$ & $\circ$ & 2 & 2 & 4 & 7 \\
\hline
\end{tabular}

The percentage improvement in efficiency of food utilization due to the $\mathrm{Cu}$ supplement was greater when feeding was semi-ad lib. than when it was to scale (see Table I3).

Rate of food consumption. Although the mean rate of food consumption was increased as a result of supplementing the diet with $\mathrm{Cu}$ as either sulphate or carbonate, the mean differences were not statistically significant for either the pigs fed to scale or those fed semi-ad lib.

Rate of food consumption was significantly higher $(P<0.001)$ for the pigs fed semi-ad lib. than for those fed to scale (Table 5).

Dressing percentage. Dressing percentage was significantly increased when the diet was supplemented with copper sulphate $(P<0.00 \mathrm{I})$, but not with copper carbonate, 
under either system of feeding (Table 5). The system of feeding itself had no effect on the dressing percentage.

Liver copper stores. Supplementation of the diet with either copper sulphate or copper carbonate resulted in large increases in the amount of $\mathrm{Cu}$ present in the livers at bacon weight, the former giving increases of similar magnitude to those obtained in Expt I when $25^{\circ}$ p.p.m. $\mathrm{Cu}$ as sulphate were added. There was some indication that the increase in liver $\mathrm{Cu}$ stores was not so great when $\mathrm{Cu}$ was given as the carbonate instead of as the sulphate, particularly with semi-ad lib. feeding.

Interaction between diet and system of feeding. For none of the variables studied was there any significant interaction $(P>0.05)$.

Commercial grading (Table I I). The commercial grading of the carcasses, based on back-fat thickness, was very similar for all groups, neither supplementation with copper nor system of feeding having any consistent effect.

Table $\mathrm{I}_{3}$. Expts $\mathrm{I}-4$. Improvement due to copper supplementation expressed as a percentage of the performance of corresponding controls not given copper

\begin{tabular}{|c|c|c|c|}
\hline \multirow[b]{2}{*}{$\begin{array}{l}\text { Expt } \\
\text { no. }\end{array}$} & \multirow[b]{2}{*}{$\begin{array}{l}\text { Copper supplement (p.p.m.) } \\
\text { and system of feeding }\end{array}$} & \multicolumn{2}{|c|}{ Improvement } \\
\hline & & $\begin{array}{l}\text { Daily weight } \\
\text { gain }\end{array}$ & $\begin{array}{l}\text { Efficiency } \\
\text { of food } \\
\text { utilization }\end{array}$ \\
\hline $\mathbf{I}$ & $\begin{array}{l}62 \cdot 5 \text { as sulphate }(\mathrm{S}) \\
\mathrm{1} 25 \text { as sulphate }(\mathrm{S}) \\
25^{\circ} \text { as sulphate (S) }\end{array}$ & $\begin{array}{l}4 \cdot 8 \\
3 \cdot 4 \\
9 \cdot 0\end{array}$ & $\begin{array}{l}4 \cdot 3 \\
4 \cdot 3 \\
5 \cdot 4\end{array}$ \\
\hline 2 & $\begin{array}{l}25^{\circ} \text { as sulphate (TS) } \\
25^{\circ} \text { as carbonate (TS) } \\
25^{\circ} \text { as sulphate (S) } \\
25^{\circ} \text { as carbonate (S) }\end{array}$ & $\begin{array}{r}5 \cdot 9 \\
8 \cdot 1 \\
11 \cdot 3 \\
9 \cdot 9\end{array}$ & $\begin{array}{l}3 \cdot 3 \\
4 \cdot 8 \\
7 \cdot 3 \\
7 \cdot 9\end{array}$ \\
\hline 3 & $\begin{array}{l}250 \text { as sulphate } \\
\text { (white-fish meal diet) (S) } \\
25^{\circ} \text { as sulphate } \\
\text { (dried skim-milk diet) (S) }\end{array}$ & I $2 \cdot 1$ & $\begin{array}{l}0.6 \\
2 \cdot 6\end{array}$ \\
\hline 4. (a) & $\begin{array}{l}25^{\circ} \text { as sulphate }(\mathrm{S}) \\
25^{\circ} \text { as sulphate }(\mathrm{A})\end{array}$ & $\begin{array}{l}13 \cdot 3 \\
10 \cdot 4\end{array}$ & $\begin{array}{l}3 \cdot 3 \\
5 \cdot 4\end{array}$ \\
\hline $4(b)$ & $25^{\circ}$ as sulphate $(A)$ & $9 \cdot 2$ & $6 \cdot 5$ \\
\hline
\end{tabular}

All figures are for an experimental period from about 9 weeks of age to bacon weight with the exception of those for Expt $4(a)$ which are for a 9-week experimental period from weaning.

(S), semi-ad lib., wet (see p. 507); (TS), to scale, wet (see p. 507); (A), ad lib., dry (see p. 507).

\section{Expt 3 (Tables 6 and $\mathbf{1 2}$ )}

Rate of gain. Supplementation with $25^{\circ}$ p.p.m. Cu of a diet containing dried skim milk as the protein supplement resulted in a rate of gain significantly higher than that obtained when the same diet was given unsupplemented (treatment 3 ) or when a diet with white-fish meal with or without a copper supplement (treatments I and 2) was given $(P<0.001)$. Supplementation of the white-fish meal diet with $\mathrm{Cu}$ resulted in an improvement in rate of gain of only $2 \cdot 6 \%$, a difference which was not statistically significant, compared with the improvement of $12 \cdot \mathrm{I} \%$ when the dried skim-milk diet was supplemented with copper sulphate. 
Efficiency of food utilization. Although the treatment mean square was not significant, a $t$ test indicated that the pigs given the dried skim-milk diet supplemented with copper sulphate (treatment 4 ) utilized their food significantly more efficiently than pigs given the white-fish meal diet, with or without a $\mathrm{Cu}$ supplement $(P<0.05)$.

Rate of food consumption. The pigs on treatment 4 (dried skim-milk diet with 250 p.p.m. $\mathrm{Cu}$ ) had a rate of food consumption significantly higher than that of the pigs on either of the other three treatments. The small increase in rate of food consumption arising from supplementation of the white-fish meal diet with $\mathrm{Cu}$ (treatments I and 2) was not statistically significant $(P>0.05)$.

Dressing percentage and carcass length. There were no significant differences between any of the treatments in either dressing percentage or carcass length.

Commercial grading (Table 12). There were no consistent differences in grading results, based on back-fat thickness and carcass length, between the four groups of pigs except that there was some indication of an increase in back-fat thickness in some of the pigs given the dried skim-milk diet with the Cu supplement.

$$
\text { Expt } 4 \text { (Tables 7, } 8 \text { and 9) }
$$

(a) For 9 weeks experimental period from weaning (Tables 7 and 8)

Rate of gain. Addition of $25^{\circ}$ p.p.m. Cu as sulphate to the diet resulted in a significant increase in rate of growth with both semi-ad lib. wet and ad lib. dry feeding. Rate of growth on the former system of feeding was significantly greater $(P<0.05)$ than on the latter (Table 8).

Efficiency of food utilization. Supplementation with copper sulphate tended to improve the efficiency of food utilization with both systems of feeding, but the differences were not significant at the $5 \%$ level. The food consumed was, however, utilized significantly more efficiently $(P<0.01)$ when given semi-ad lib. wet than when given ad lib. dry (Table 8).

Rate of food consumption. With both feeding systems, $\mathrm{Cu}$ supplementation tended to result in a higher rate of food consumption, and the increase was statistically significant $(P<0.05)$ for the combined results (Table 8$)$. The system of feeding had no significant effect on rate of food consumption.

Interaction between diet and system of feeding. For none of the variables studied was there any significant interaction $(P>0.05)$.

(b) For experimental period from weaning to bacon weight for pigs fed ad lib. on dry meal to a maximum of $6 \frac{3}{4} \mathrm{lb} /$ pig daily (Table 9)

Supplementation of the diet with copper sulphate resulted in a significant increase in live-weight gain, and a tendency for improved efficiency of food utilization which was not significant at the $5 \%$ level. The rate of food consumption was very similar in both groups.

When the diet was supplemented with copper sulphate there was a marked increase in mean liver copper stores at slaughter. 


\section{DISCUSSION}

The marked growth-promoting effect of supplementing a growing-pig diet with $\mathrm{Cu}$ was again confirmed. The magnitude of the responses was similar to that usually obtained previously (see Barber et al. 1960), except for the pigs in Expt 3, given the diet with white-fish meal as the protein supplement. The performance of the animals given a white-fish meal diet supplemented with copper sulphate was very similar in all respects in the four experiments, whereas the performance of the control pigs in Expt 3 was markedly superior to that of the control animals in the other three experiments. This finding suggests that the failure to show any significant response to the addition of $\mathrm{Cu}$ to the white-fish meal diet in Expt 3 was due, at least in part, to the fact that, for unknown reasons, the general level of performance of the control pigs was appreciably better than normal in this particular trial (see Barber, Bowland, Braude, Mitchell \& Porter, 196r). In spite of it, however, a very marked response was obtained in this experiment when the diet containing dried skim milk, instead of white-fish meal as the protein supplement, was supplemented with copper sulphate. Although the total crude-protein content of the white-fish meal and dried skim-milk diets (diets I and 3 , Table I) was about the same, the energy value of the skim-milk diet was about $5 \%$ higher and the diet differed from the fish-meal diet in that it contained lactose. Further work is now in progress to investigate the possible significance of these dietary differences in relation to the use of supplementary $\mathrm{Cu}$.

Although all three levels of copper sulphate used in Expt. I gave significant increases in growth rate and efficiency of food utilization, the best response was obtained with the highest level (250 p.p.m. Cu). Lucas \& Calder (1957) reported no significant difference in the performance of pigs given either $125^{\circ}$ or $25^{\circ}$ p.p.m. Cu, but Dammers $\&$ van der Grift (1959) concluded that I25 p.p.m. Cu was not quite sufficient to give the optimal response, since either 187.5 or $25^{\circ}$ p.p.m. Cu gave rather better responses, there being no difference between the two latter levels.

The large increase in liver $\mathrm{Cu}$ stores shown in Tables 3,4 and 9 when a diet with $25^{\circ}$ p.p.m. Cu added was given, is in agreement with previously reported results (see Barber et al. 196I). It is clear from all our results, and from those reported by other workers, that there can be very wide variation in the liver Cu levels both between individual pigs in any one experiment and between groups of pigs in different experiments, both with pigs given low- $\mathrm{Cu}$ control diets and those given $\mathrm{Cu}$-supplemented diets. Average figures for liver $\mathrm{Cu}$ content can, therefore, be misleading. The absence of any increase in liver $\mathrm{Cu}$ when only 62.5 p.p.m. Cu were added to the diet, and the relatively small increase when 125 p.p.m. Cu were added, as compared with the large increase resulting from the addition of $25^{\circ}$ p.p.m. Cu, was also found by Lucas \& Calder (1957) and by Dammers \& van der Grift (1959). The latter workers also obtained evidence that the increase in liver copper content after the addition of 187.5 p.p.m. Cu was very appreciably less than that when $25^{\circ}$ p.p.m. $\mathrm{Cu}$ were added to the diet. It appears that quite high levels of dietary $\mathrm{Cu}$ can be fed to pigs without any appreciable liver storage taking place, but that once storage begins it increases markedly with increasing levels of dietary $\mathrm{Cu}$. 
Barber et al. (1960) concluded that when pigs are fed in a way that allows some expression of appetite the improvement in rate of growth resulting from supplementing the diet with $\mathrm{Cu}$ was the direct consequence partly of an improvement in the efficiency with which the food consumed was utilized and partly of an increase in the rate of food consumption. The results of the four experiments reported here support this conclusion, although in one or two instances mean differences in these two variables between the control and supplemented groups were relatively small and not statistically significant at the conventional level. In Expt 2, for example, $\mathrm{Cu}$ supplementation resulted in only small, statistically not significant, increases in rate of food consumption both with the pigs fed to scale and those fed semi-ad lib. In the former, theoretically no expression of appetite should be possible at all. In practice, however, the pigs given one of the $\mathrm{Cu}$-supplemented diets tended to eat completely their daily allocation of food soon after the beginning of the experiment, whereas the control pigs often refused small amounts of food daily for several days after the trial began. Hence some slight appetite effect was unavoidably introduced. Nevertheless, the figures in Table $\mathrm{I} 3$ indicate that a greater response to $\mathrm{Cu}$ supplementation both in rate of gain and efficiency of food utilization may be expected when pigs are fed on the semi-ad lib. system (as defined on p. $5^{\circ} 7$ ) instead of according to live weight and the scale used in these experiments.

On the other hand, the magnitude of the response to $\mathrm{Cu}$ supplementation on semiad lib. wet and fully ad lib. dry feeding was similar with both systems of feeding. Rate of growth, however, was significantly better with the semi-ad lib. system of feeding (see Table 8). This difference was apparently the result of a significantly better efficiency of food utilization, since there was no difference in rate of food consumption between the pigs on the two systems of feeding. Owing to the small number of animals involved in this particular comparison, and the fact that the experiment covered a period of only 9 weeks from weaning, further work is necessary before any conclusions can be drawn about these apparent differences between semi-ad lib. wet and $a d$ lib. dry feeding.

Barber et al. (1961) discussed the reported observations on the effect of Cu supplementation on dressing percentage and considered that the evidence available indicated that there was a real increase in dressing percentage associated with the growth response obtained with high-Cu diets. Further confirmation of this trend was obtained in the experiments now described, although some mean differences were small. Results obtained in Expt 2 suggested that the increase in dressing percentage may be less, or perhaps not occur at all, when copper carbonate instead of copper sulphate is used. Further results must be obtained to determine whether this apparent difference in the effects of the two $\mathrm{Cu}$ salts is a real treatment effect, because if confirmed it might prove to be a finding of some importance in relation to studies on the mode of action of $\mathrm{Cu}$. In this connexion, Wacker, Heyl, Büechl \& Holthoff (1956) suggested that the growthpromoting effect of copper sulphate that they observed in chicks may be due, at least in part, to the increased sulphur content of the diet. The identical growth responses to supplements of either copper sulphate or copper carbonate obtained in Expt 2 provide convincing evidence that, in pigs at any rate, it is $\mathrm{Cu}$ itself that is responsible for the observed effects. 
The absence of any consistent effect of $\mathrm{Cu}$ supplementation on commercial grading results is in agreement with the results of the majority of previously reported experiments. In one experiment, however, reported by Barber et al. (I961), Cu supplementation was accompanied by a marked down-grading of the carcasses, which reflected an increase in thickness of fat along the back. In one of the trials reported by Dammers \& van der Grift (1959) there was also a marked increase in the back-fat thickness of carcasses from pigs given a diet with either 125 or $25^{\circ}$ p.p.m. Cu added. There was a suggestion of a similar trend in the one experiment reported here in which $\mathrm{Cu}$ was added to the diet containing dried skim milk instead of white-fish meal as the protein supplement. It would appear that under certain conditions $\mathrm{Cu}$ supplementation of growing-pig diets may be associated with some increase in carcass fatness, although the evidence obtained so far suggests that usually no such adverse effects result. Further work is now in progress on this important problem.

\section{SUMMARY}

I. One-hundred-and-sixty individually fed, virus pneumonia-free Large White weaners were used in four experiments to determine the effects of dietary supplements of copper given either as the sulphate or the carbonate, at various levels, and under different feeding systems as shown in detail in Table 2. In all experiments except Expt 4, the experimental period continued from weaning to bacon weight. In Expt 4, some of the pigs were on experiment for 9 weeks only from weaning.

2. The marked growth-promoting effect of $\mathrm{Cu}$ was again confirmed. In general, this effect on growth rate was associated with an improvement in efficiency of food conversion and with an increase in the rate of food consumption.

3. Levels of $62.5,125$ and $25^{\circ}$ p.p.m. supplementary $\mathrm{Cu}$ in the diet all resulted in significant improvements in both growth rate and efficiency of food utilization. The highest rate of growth occurred in the pigs given the diet with the highest level of $\mathrm{Cu}$.

4. Copper carbonate was equally as effective as copper sulphate in improving the performance of the pigs.

5. The percentage improvement in performance resulting from the addition of dietary $\mathrm{Cu}$ with either 'semi-ad lib.' wet, or 'ad lib.' dry, feeding tended to be slightly higher than with 'to scale' wet feeding.

6. The highest rates of growth and efficiency of food utilization were obtained when a diet containing dried skim milk, instead of white-fish meal as the protein supplement, was supplemented with $\mathrm{Cu}$.

7. There were very large increases in the amount of $\mathrm{Cu}$ in the liver at slaughter when a diet with $25^{\circ}$ p.p.m. Cu added was given. When the level of $\mathrm{Cu}$ added was 62.5 or I25 p.p.m., no, or only very small, increases in liver $\mathrm{Cu}$ stores occurred. There were very wide variations in liver $\mathrm{Cu}$ levels between individual pigs both within and between experiments.

8. Supplementation of the diet with copper sulphate tended to increase the dressing percentage. Dietary supplementation with $\mathrm{Cu}$ had no consistent effect on the commercial grading of the resulting carcasses, with the exception that there was a 
suggestion that back-fat thickness was increased in some pigs when a diet containing dried skim milk was supplemented with $\mathrm{Cu}$.

\section{REFERENCES}

Andrus, S. (1955). Analyst, 80, 514.

Barber, R. S., Bowland, J. P., Braude, R., Mitchell, K. G. \& Porter, J. W. G. (196r). Brit. F. Nutr. 15,189 .

Barber, R. S., Braude, R. \& Mitchell, K. G. (1957). F. agric. Sci. 48, 347.

Barber, R. S., Braude, R. \& Mitchell, K. G. (1960). Brit. F. Nutr. 14, 499.

Barber, R. S., Braude, R., Mitchell, K. G. \& Cassidy, J. (1955). Chem. E' Ind. p. 6or.

Braude, R. \& Mitchell, K. G. (I95I). Agriculture, Lond., 57, 501 .

Dammers, J. \& van der Grift, J. (1959). Versl. Inst. landb. Onderz., Wageningen, no. 65.12, p. 7.

Lucas, I. A. M. \& Calder, A. F. C. (1957). Proc. Nutr. Soc. 16, i.

Wacker, A., Heyl, W., Büechl, H. \& Holthoff, H. J. (1956). Arzneimitt. Forsch. 6, 712.

Yates, F. (1933). Emp. F. exp. Agric. I, 129. 